\title{
Maternal Education Level and Child's Anxiety on Dental Extraction
}

\author{
Jeffrey, Florence Meliawaty, Asih Rahaju \\ Dentistry Studies Program \\ Faculty of Medicine University of Jenderal Achmad Yani \\ Terusan Jend. Sudirman PO. BOX 148, Cimahi-40533, Indonesia \\ Email: jeffrey_dent2000@yahoo.com
}

\begin{abstract}
Dental extraction can cause anxiety in children, observed in vital signs changes. If occurs excessively, it can be regarded as an obstacle and may affect a child's behavior that can further determine the success of dental treatment. Anxiety that occurs in children can usually be influenced by various factors, including the level of parental education. This study aimed to observe maternal education level and anxiety in children receiving dental extraction treatments. This is a descriptive study, involving 60 subjects aged 7-12 that went for dental extraction at Rumah Sakit Gigi Mulut Pendidikan Universitas Jenderal Achmad Yani (RSGMP UNJANI) Cimahi Juli-Desember 2016. The parameters examined for measuring anxiety are body temperature, respiration frequency, and pulse before and after the procedure. This study found that $63.3 \%$ of mother of the subject had high school education, $16.7 \%$ of junior high school, $8.3 \%$ S1, 6.7\% D1/D3, and 5\% SD. Increased body temperature was obtained in 36 subjects, increased respiration frequency in 46 subjects, and increased pulse in 34 subjects. We concluded that the majority of maternal education levels in this study are high school graduates and the anxiety parameters in the majority of subjects increase when receiving dental extraction procedure.
\end{abstract}

Keywords: child's anxiety, dental extraction, mother education level 


\title{
Gambaran Tingkat Pendidikan Ibu dan Kecemasan Anak saat Menerima Tindakan Ekstraksi Gigi
}

\author{
Jeffrey, Florence Meliawaty, Asih Rahaju \\ Program Studi Kedokteran Gigi \\ Fakultas Kedokteran Universitas Jenderal Achmad Yani \\ Terusan Jend. Sudirman PO. BOX 148, Cimahi - 40533 \\ Email: jeffrey_dent2000@yahoo.com
}

\begin{abstract}
Abstrak
Tindakan ekstraksi gigi merupakan salah satu tindakan di bidang kedokteran gigi yang dapat menyebabkan rasa cemas pada anak yang dapat terlihat pada perbedaan tanda-tanda vital pada tubuh. Apabila kecemasan ini terjadi secara berlebihan, hal ini dapat dianggap sebagai hambatan dan dapat mempengaruhi tingkah laku anak yang lebih jauh lagi dapat menentukan keberhasilan perawatan gigi. Kecemasan yang terjadi pada anak biasanya dapat dipengaruhi oleh berbagai faktor, di antaranya adalah tingkat pendidikan orang tua. Penelitian ini bertujuan untuk mengetahui gambaran tingkat pendidikan ibu dari subjek yang melakukan prosedur ekstraksi gigi dan kecemasan pada subjek saat menerima tindakan ekstraksi gigi. Ini merupakan penelitian deskriptif, melibatkan 60 anak usia 7-12 tahun yang menjalani prosedur ekstraksi gigi di Rumah Sakit Gigi Mulut Pendidikan Universitas Jenderal Achmad Yani (RSGMP UNJANI) Cimahi Juli-Desember 2016. Parameter yang diperiksa untuk mengukur kecemasan adalah suhu tubuh, frekuensi respirasi, dan denyut nadi sebelum dan setelah tindakan. Hasil penelitian ini menemukan $63,3 \%$ ibu subjek memiliki tingkat pendidikan SMA, 16,7\% SMP, 8,3\% S1, 6,7\% D1/D3, dan 5\% SD. Peningkatan suhu tubuh didapatkan pada 36 subjek, peningkatan frekuensi respirasi pada 46 subjek, dan peningkatan nadi pada 34 subjek. Sebagai simpulan, mayoritas tingkat pendidikan ibu adalah SMA dan parameter kecemasan pada mayoritas subjek meningkat saat menerima tindakan ekstraksi gigi.
\end{abstract}

Kata kunci: ekstraksi gigi, kecemasan anak, tingkat pendidikan ibu 
Research Article

\section{Pendahuluan}

Data Riset Kesehatan Dasar (RISKESDAS) tahun 2013 menunjukkan bahwa penduduk Indonesia yang memiliki masalah gigi dan mulut sebesar $25,9 \%$ dan hanya sekitar $31,1 \%$ yang menerima perawatan dan pengobatan gigi mulut dari tenaga medis (perawat gigi, dokter gigi atau dokter gigi spesialis), sedangkan 68,9\% lainnya tidak menerima perawatan gigi dan mulut. Terdapat berbagai macam perawatan gigi yang diterima masyarakat, salah satunya adalah ekstraksi gigi yang merupakan suatu tindakan di bidang kedokteran gigi dengan tujuan untuk mencabut atau mengeluarkan gigi dari tulang alveolar. Hal ini dapat menyebabkan pasien mengalami kecemasan, yang terjadi akibat penggunaan alat seperti jarum suntik, tang, dan bein saat ekstraksi gigi. ${ }^{1,2}$

Kecemasan yang timbul pada anak merupakan reaksi emosi normal atau wajar karena situasi yang dihadapinya merupakan hal yang baru, yang biasanya ditandai oleh rasa khawatir. Rasa cemas ini biasanya akan menjadi hambatan bagi tenaga kesehatan dalam upaya pelayanan kesehatan gigi dan mulut, bahkan dapat menyebabkan terjadinya beberapa masalah. Pada pasien yang belum memiliki pengalaman dilakukan ekstraksi, timbul rasa cemas yang dapat diakibatkan oleh beberapa faktor, di antaranya karena mendengar pengalaman dari orang lain dan kurangnya pengetahuan atau informasi mengenai perawatan yang akan dilakukan. ${ }^{1,2}$

Kecemasan merupakan hambatan bagi dokter gigi dalam menjalankan perawatan gigi, khususnya tindakan ekstraksi gigi, sehingga hal ini menjadi alasan orang tua untuk mengabaikan perawatan gigi anaknya. Anak sering merasa cemas sebelum dan sesudah perawatan gigi. Dalam kondisi cemas pasien dapat mengalami berbagai perubahan fisiologis, seperti perubahan denyut jantung, pembuluh darah, gangguan pencernaan, dan histeria. Untuk mengukur tingkat kecemasan seseorang maka perlu dilakukan suatu penilaian dan pemeriksaan baik secara fisiologis, emosional, dan kognitif dari pasien, seperti adanya tanda fisiologis yang ditandai dengan peningkatan denyut nadi dan berkeringat. ${ }^{1-3}$

Kecemasan pada anak-anak merupakan masalah yang menyebabkan anak sering menunda dan menolak perawatan gigi. Salah satu aspek terpenting dalam perawatan gigi anak adalah mengontrol rasa sakit, karena pengalaman yang tidak menyenangkan akan berdampak di masa depan. Penundaan perawatan gigi dapat menyebabkan tingkat kesehatan mulut pasien bertambah parah dan menambah ketakutan anak untuk berobat ke dokter gigi. ${ }^{3}$

Berdasarkan beberapa penelitian, telah diketahui bahwa kecemasan dental pada anak biasanya dapat dipengaruhi oleh beberapa faktor, diantaranya jenis kelamin, usia, kecemasan orang tua, nyeri saat perawatan gigi, dan juga pendidikan ibu. ${ }^{4}$ Pengaruh orang tua sangat penting terhadap pembentukan perilaku anak dalam menjalani perawatan gigi. Orang tua harus menginformasikan kepada anak tentang apa yang sebaiknya dia lakukan selama berada di praktek dokter gigi. Anak 
harus terlebih dahulu diberi gambaran tentang dokter yang akan merawatnya serta situasi yang dapat timbul nanti sebelum membuat janji bertemu dengan dokter gigi, tidak perlu menceritakan rasa sakit yang begitu hebat kepada anak, tetapi diperlukan pernyataan yang jujur tanpa emosi yang dilebihlebihkan. $^{5}$

Berdasarkan latar belakang di atas maka peneliti tertarik untuk meneliti gambaran tingkat pendidikan ibu dan kecemasan anak yang menerima perawatan ekstraksi gigi sulung di Rumah Sakit Gigi Mulut Pendidikan Universitas Jenderal Achmad Yani (RSGMP UNJANI), Cimahi.

\section{Metode}

Penelitian yang dilakukan adalah penelitian deskriptif untuk mengetahui gambaran tingkat pendidikan orang tua dan kecemasan anak saat menerima tindakan pencabutan gigi. Populasi dalam penelitian ini adalah pasien anak yang datang ke Rumah Sakit Gigi Mulut Pendidikan Universitas Jenderal Achmad Yani (RSGMP UNJANI), Cimahi periode Juli hingga Desember 2016. Sampel dalam penelitian ini adalah pasien anak yang memenuhi kriteria inklusi dan eksklusi.

Kriteria inklusi dalam penelitian ini adalah laki-laki dan perempuan berusia 7-12 tahun, bersedia untuk dilakukan pemeriksaan, telah mendapatkan ijin dari orang tua atau wali, sehat jasmani dan rohani, perawatan dilakukan oleh dokter gigi muda, ekstraksi gigi sulung dengan teknik infiltrasi. Kriteria eksklusinya yaitu tidak kooperatif dalam perawatan gigi, menderita kelainan sistemik, sudah pernah dilakukan perawatan ekstraksi gigi sulung dengan teknik infiltrasi sebelumnya, dan anak yang tidak diasuh oleh ibu. Jumlah sampel pada penelitian ini adalah 60 orang.

Alur penelitian yang dilakukan diawali dengan membuat surat perijinan ke bagian akademik untuk mendapatkan ijin penelitian dari Karumkit RSGMP UNJANI Cimahi dan persetujuan Komisi Etik Kedokteran No. 600/UN6.C1.3.2/KEPK/PN/2016. Pengambilan sampel dilakukan setelah pasien anak memperoleh nomor rekam medik di RSGMP Unjani. Pelaksanaan penelitian diawali dengan menyeleksi pasien sesuai kriteria pemilihan. Peneliti memperkenalkan diri, menjelaskan maksud dan tujuan serta prosedur penelitian kepada orang tua atau wali dan pasien anak. Peneliti memberikan lembar persetujuan (informed consent) yang harus ditandatangani oleh orangtua atau wali untuk mendapatkan ijin. Pasien yang memenuhi kriteria inklusi akan dilakukan pemeriksaan tanda vital (suhu, denyut nadi, dan respirasi) sebelum dan setelah tindakan. 


\section{Research Article}

\section{Hasil}

Pada tabel 1 terlihat dari 60 orang subjek penelitian, responden mayoritas berjenis kelamin perempuan (65\%) dengan jenjang pendidikan terakhir ibu terbanyak adalah SMA (63,3\%). Karakteristik selengkapnya mengenai responden dokter gigi tersaji pada tabel 1.

Tabel 1 Karakteristik Responden

\begin{tabular}{ccllcc}
\hline No & $\begin{array}{c}\text { Karakteristik } \\
\text { Responden }\end{array}$ & Keterangan & Frekuensi (f) & $\begin{array}{c}\text { Persentase } \\
(\%)\end{array}$ \\
\hline 1. & Jenis Kelamin & a. & Laki-laki & 21 & 35 \\
& b. & Perempuan & 39 & 65 \\
\hline 2. & Pendidikan Ibu & a. & SD & 3 & 5 \\
& Responden & b. & SMP & 10 & 16,7 \\
& & c. & SMA & 38 & 63,3 \\
& & d. & D1/D3 & 4 & 6,7 \\
& & e. & S1 & 5 & 8,3 \\
\hline
\end{tabular}

Pada tabel 2 tersaji bahwa peningkatan suhu tubuh didapatkan pada 36 subjek, peningkatan frekuensi respirasi pada 46 subjek, dan peningkatan nadi pada 34 subjek.

Tabel 2 Gambaran Perubahan Suhu, Respirasi dan Denyut Nadi Pasca Ekstraksi Gigi

\begin{tabular}{llllllllll}
\hline & \multicolumn{2}{l}{ Naik } & \multicolumn{2}{l}{ Tetap } & \multicolumn{2}{c}{ Turun } & \multicolumn{2}{c}{ Total } \\
\cline { 2 - 10 } & $\mathrm{f}$ & $\%$ & $\mathrm{f}$ & $\%$ & $\mathrm{f}$ & $\%$ & $\mathrm{f}$ & $\%$ \\
\hline Perubahan suhu & 36 & 60 & 7 & 11,7 & 17 & 28,3 & 60 & 100 \\
Perubahan respirasi & 46 & 76,7 & 7 & 11,7 & 17 & 28,3 & 60 & 100 \\
Perubahan denyut nadi & 34 & 56,7 & 1 & 1,7 & 25 & 41,7 & 60 & 100 \\
\hline
\end{tabular}

\section{Gambar 1 Gambaran Perubahan Suhu, Respirasi dan Denyut Nadi}

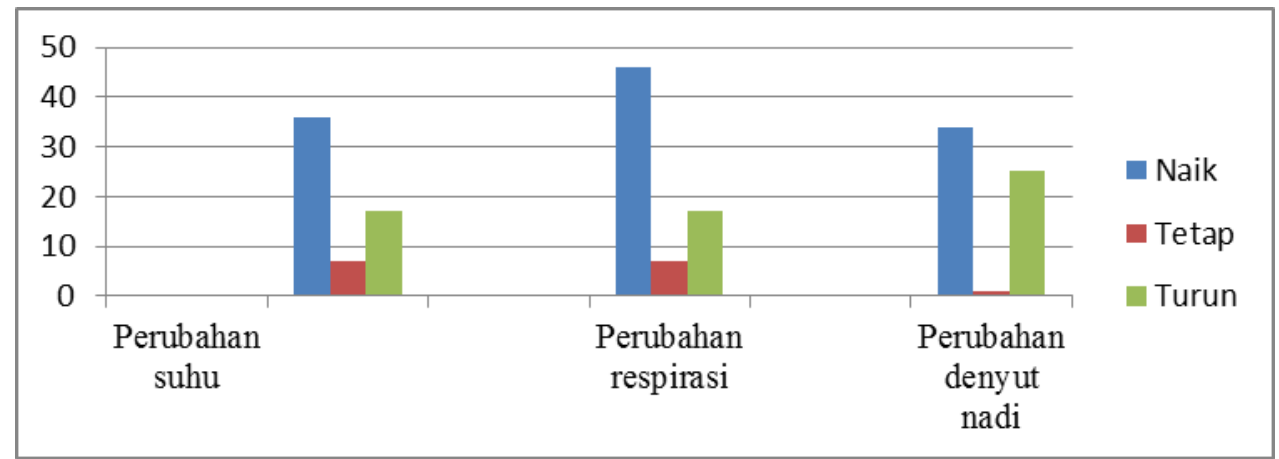




\section{Diskusi}

Hasil penelitian menemukan 63,3\% ibu subjek memiliki tingkat pendidikan SMA, 16,7\% SMP, 8,3\% S1, 6,7\% D1/D3, dan 5\% SD. Parameter kecemasan, yaitu peningkatan suhu tubuh didapatkan pada 36 subjek, peningkatan frekuensi respirasi pada 46 subjek, dan peningkatan nadi pada 34 subjek.

Kecemasan merupakan perasaan emosional yang tidak nyaman yang disebabkan oleh sesuatu yang kurang jelas. Kecemasan biasanya terjadi akibat kondisi yang tidak menyenangkan pada anak dan juga pengaruh keluarga. Kecemasan juga dapat diartikan sebagai kondisi emosional yang membantu individu sebagai mekanisme pertahanan diri melawan berbagai ancaman. Kondisi ini merefleksikan kombinasi biokimia di dalam tubuh pasien yang terdiri atas sejarah, memori, dan status sosial. $^{6-8}$

Kecemasan dental dapat didefinisikan sebagai rasa takut yang abnormal atau rasa takut akibat berkunjung ke dokter gigi untuk menerima tindakan pencegahan atau terapi dan kecemasan ini terjadi secara tidak jelas selama prosedur dental, yang akan menyebabkan dampak secara fisiologis, psikologis, dan perubahan tingkah laku. Kondisi ini merupakan suatu masalah yang sering terjadi. Kecemasan dental ini biasanya dikaitkan dengan lingkungan kedokteran gigi dan tindakan dental yang spesifik. ${ }^{6,89}$

Beberapa tindakan di bidang kedokteran gigi dapat menyebabkan rasa takut dan kecemasan pada pasien. Tindakan anestesi yang dilakukan biasanya bertujuan untuk menghilangkan rasa sakit dan membuat perawatan menjadi lebih mudah, tetapi hal ini malah mengakibatkan rasa takut dan menghasilkan kecemasan yang parah pada pasien. Kecemasan yang dikaitkan dengan tindakan ekstraksi gigi merupakan suatu fenomena yang wajar. Kecemasan selama tindakan pencabutan gigi biasanya dipengaruhi penggunaan anestesi dengan menggunakan jarum suntik dan penggunaan instrumen lain di bidang kedokteran gigi. ${ }^{7}$

Penyebab terjadinya kecemasan dental ini bersifat multifaktorial, dan terdapat beberapa faktor yang berhubungan dengan terjadinya insidensi kecemasan, di antaranya karakteristik personal, jenis rasa sakit, pengalaman trauma dental sebelumnya terutama pada anak-anak, pengaruh kecemasan dental dari anggota keluarga, pengaruh negatif dari ibu, ketakutan akan darah dan luka, faktor sosial ekonomi, dan faktor pendidikan. ${ }^{3,8-10}$ Intensitas dan prevalensi kecemasan biasanya terjadi berbedabeda pada setiap kelompok orang; kelompok dengan status sosial ekonomi yang rendah ataupun dengan tingkat pendidikan yang rendah biasanya akan mengalami tingkat kecemasan yang lebih berat. $^{7-9}$

Contoh yang kurang baik dan pengalaman yang disampaikan oleh orang tua kepada anaknya, merupakan salah satu faktor etiologi yang menimbulkan rasa takut dan kecemasan dental yang dialami anak. Hal ini memiliki konsekuensi status kesehatan rongga mulut yang buruk. Pengaruh dari 


\section{Research Article}

ibu biasanya dikaitkan dengan pengalaman rasa nyeri yang ibu alami dan hal ini dapat menjadi faktor penyebab peningkatan rasa takut dan kecemasan pada anak, dapat disebut sebagai pengaruh negatif dari ibu. ${ }^{8-10}$

Berdasarkan beberapa penelitian yang telah dilakukan, diketahui bahwa anak-anak yang telah mendapatkan pengetahuan yang baik mengenai tindakan di bidang kedokteran gigi akan memiliki level kecemasan dental yang lebih baik apabila dibandingkan dengan anak-anak yang sama sekali tidak pernah mengetahui tindakan di bidang kedokteran gigi. Tindakan yang paling menakutkan di bidang kedokteran gigi adalah anestesia dengan menggunakan injeksi, sehingga hal ini merupakan sumber mayor terjadinya kecemasan dental. ${ }^{6}$

Di bidang kedokteran gigi, prosedur ekstraksi, penyuntikan, dan pengeboran merupakan keadaan yang dapat memicu terjadinya kecemasan. Prosedur ekstraksi gigi merupakan penyebab kecemasan dental yang paling tinggi yang ditakuti oleh anak-anak dan menyebabkan trauma saat dewasa. Ekstraksi gigi adalah cabang ilmu kedokteran gigi yang berhubungan dengan prosedur pencabutan gigi dari soketnya di dalam tulang., ${ }^{3,11}$

Indikasi ekstraksi gigi antara lain karies dalam dengan patologi pulpa; baik akut maupun kronis dan perawatan endodontik tidak memungkinkan dilakukan, gigi dengan patologi akar, gigi non-vital, periodontitis, malposisi dan gigi overerupsi, impaksi, persistensi gigi sulung, gigi pada garis fraktur; gigi yang berada pada garis fraktur harus dicabut jika berpotensi menjadi sumber infeksi dan retensinya akan mengganggu dengan penurunan bagian dari fraktur, gigi dengan fraktur akar, tujuan ortodontik, tujuan prostodontik, sebelum terapi radiasi, sisa akar, gigi yang fraktur khususnya pada bagian mesiodistal atau pada garis servikal, gigi supernumerary, gigi yang terlibat dengan kista atau tumor rahang, serta penyakit periodontal dengan gigi goyang derajat II dan III. ${ }^{3,11,12}$

Tingkat pendidikan formal merupakan dasar pengetahuan intelektual yang dimiliki seseorang. Hal ini erat kaitannya dengan pengetahuan, karena semakin tinggi pengetahuan, maka semakin besar kemampuan menyerap dan menerima informasi sehingga akan memiliki pengetahuan dan wawasan yang lebih luas. Pengetahuan merupakan hasil dari tahu dan ini terjadi melalui panca indra manusia dan hal ini sangat mempengaruhi seseorang dalam menghadapi masalah. Seseorang yang memiliki pengetahuan yang cukup akan sesuatu hal, cenderung untuk memiliki kecemasan yang ringan dibandingkan dengan yang pengetahuannya kurang. Kurangnya pengetahuan, khususnya pengetahuan mengenai perawatan gigi dapat menyebabkan timbulnya rasa cemas pada perawatan gigi. Hal ini disebabkan kurangnya informasi yang diperoleh mengenai perawatan gigi, sehingga mereka menganggap hal tersebut adalah sesuatu yang menakutkan. Oleh karena itu diketahui bahwa terdapat hubungan antara tingkat pengetahuan yang dimiliki oleh seseorang dengan tingkat kecemasan yang terjadi. $^{3,13}$ 


\section{Research Article}

Penjelasan mengenai tindakan perawatan yang akan dilakukan perlu disampaikan sebelum dilakukan perawatan, sehingga anak lebih mengerti mengenai apa yang akan dilakukan dan ini membantu pasien dalam mengontrol kecemasan. Tingkah laku dan umur yang berbeda pada anak menyebabkan dokter gigi harus mampu bersikap berbeda dalam mengatasinya. Beberapa hal yang dapat dilakukan oleh seorang dokter gigi di antaranya memberikan pertanyaan sebelum, selama, dan setelah perawatan sehingga dapat membangkitkan rasa percaya dan memberikan kesempatan kepada anak untuk bekerja sama. Selain itu anak diberi kesempatan memegang alat dan menjelaskan fungsi masing-masing alat. Hal tersebut diharapkan mengurangi rasa takut dan meningkatkan perhatian. Memperkenalkan anak dengan ruang perawatan gigi dan jenis perawatan akan dilakukan sebaiknya tanpa membuat rasa takut, sehingga anak lebih percaya diri, kooperatif, dan rasa takut berubah menjadi keingintahuan. ${ }^{3,8,10}$

Peneliti menyarankan perlunya penelitian lanjutan mengenai kecemasan dental yang disertai intervensi disebabkan kecemasan dental merupakan fenomena yang kompleks multi dimensi dan sebagai dokter gigi perlu menjalin komunikasi yang baik terhadap pasien karena dengan komunikasi yang baik maka pasien akan merasa lebih tenang selama perawatan gigi.

\section{Simpulan}

Berdasarkan hasil penelitian disimpulkan bahwa mayoritas tingkat pendidikan ibu adalah SMA dan parameter kecemasan pada mayoritas subjek penelitian meningkat saat menerima tindakan ekstraksi gigi.

\section{Daftar Pustaka}

1. Yahya NB, Michael AL, Bernart SPH. Gambaran kecemasan pasien ekstraksi gigi di Rumah Sakit Gigi dan Mulut (RSGM) UNSRAT. Jurnal Ilmiah Farmasi. 2016;5(1):39-45.

2. Merinchiana, Hendri O, Jimmy M. Gambaran kecemasan pasien ekstraksi gigi sebelum dan sesudah menghirup aroma terapi lavender. Jurnal e_Gigi. 2015;3(2):391-7.

3. Permatasari R. Hubungan kecemasan dental dengan perubahan tekanan darah pasienekstraksi gigi di Rumah Sakit Gigi dan Mulut Pendidikan (RSGMP) HJ.Halimah DG. Sikati Makasar. Skripsi Fakultas Kedokteran Gigi Universitas Hasanuddin; 2013.

4. Fernanda CS, Rodrigo AL, Mauro VGB, Viviane. Factors associated with dental anxiety in Brazilian children of 5 to 8 years. BRPDIC. 2014;14(2):97-105.

5. Pertiwi ASP, Lenny K, Hendriati A. Model hubungan dental belief orang tua dengan terbentuknya dental fear anak pra-sekolah di Kota Bandung. Bandung: Pustaka Ilmiah Universitas Padjadjaran; 2015.

6. Sghaireen MG, Abdalwhab MAZ, Ibrahim AA, Sadeq MQ, Mahmoud KA. Anxiety due to dental treatment and procedures among university students: its correlation with their gender and field of study. Int J Dent. 2013;13:1-5.

7. Shitole S, Mounesh KCD, Suresh KV, Pakar MI, Pankaj BP, Ashwinirani SR. Assesment of dental anxiety in patients undergoing surgical extraction of teeth: study from Western Maharashtra. British Biomed Bulletine. 2015;3(2):232-38.

8. Hmud R, Walsh LJ. Dental anxiety: causes, complication, and management approach. J Minimum Intervent Dent. 2009; 2(1):67-78.

9. Assuncao CM, Estela M, Roberto A, Jose VN. The relationship between dental anxiety in children adolescents and their parents at dental environtment. J Indian Soc Ped Prev Dent. 2013; 31(3):175.

10. Oliviera MMT, Viviane C. The relationship between dental anxiety and dental pain in children aged 18 to 59 month: a study in Recife, Pernambuco State Brazil. Cad. Saude Publica. 2009; 25(4): 743-50.

11. Balaji SM. Textbook of oral and maxillofacial surgery. New Delhi: Elsevier; 2009. 


\section{Research Article}

12. Sanghai S. A concise textbook of oral and maxillofacial surgery. New Delhi: Jaypee Brothers Medical Publishers; 2009.

13. Rinaldi PA, Opod H, Cicilia P. Hubungan pengetahuan dengan tingkat kecemasan ibu yang anaknya dirawat RSUP Prof. DR. R. D. Kandou. Jurnal e-Biomedik. 2013;1(3):1101-5. 